\title{
Putting Technological, Pedagogical, and Content Knowledge (TPACK) in Action: An Advanced Wiki-Based Collaborative Process Writing Pedagogy (AWCPWP)
}

\author{
Xuanxi Li
}

\begin{abstract}
This research aims to develop a conceptual model of Advanced Wiki-based Collaborative Process Writing Pedagogy (AWCPWP) based on the technological pedagogical content knowledge (TPACK) theoretical framework. In order to fulfill the research purpose, this study investigated students and teacher's perception and attitudes towards a Developing Wiki-based Collaborative Process Writing Pedagogy (DWCPWP). Participants included 54 primary four students from a same class and their Chinese language teacher in Shenzhen, China. Both quantitative and qualitative methods, including course feedback questionnaire, interviews, and teacher's questionnaire, were used to collect data. The results showed that the Chinese language teachers and most students had positive attitudes and perceptions towards DWCPWP. The results also revealed teacher and students' criticism as well as suggestions on DWCPWP, based on which, this study put forward a conceptual model of AWCPWP.
\end{abstract}

Index Terms-TPACK, DWCPWP, AWCPWP.

\section{INTRODUCTION}

In recent years, with the wide application of information technology in education, teachers are also facing with new challenges [1]-[3]. Based on the Technological Pedagogical and Content Knowledge (TPACK) framework [1], in order to use technology effectively in their teaching, teachers must be knowledgeable about the relationship among technology, content, and specific pedagogies [3]. Teachers should show how technology could be used to support the learning of specific content as well as how specific pedagogies best support the use of technology and facilitate learning [3]. According to Mishra and Koehler, the TPACK framework better reflected the interdependence of three contributing knowledge domains, which are Content Knowledge (CK), Pedagogical Knowledge (PK), and Technology Knowledge (TK) [1].

Previous studies have shown that the TPACK of pre-service teachers is influenced by how their instructors integrated technology in their teaching activities and how they explained the link between the selected teaching method/activity, the specific content to be taught and the choice of the ICT application to support the teaching method/activity selected [4]. Particularly, TPACK-in-action has become a critical focus

Manuscript received September 7, 2017; revised November 10, 2017.

Xuanxi $\mathrm{Li}$ is with the Shanghai Normal University, China (e-mail petrel6688@126.com). in order to understand how TPACK is reflected in practice [5]

$\mathrm{Li}, \mathrm{Chu}, \mathrm{Ki}$ and Woo designed and orchestrated a Wiki-based Collaborative Process Writing Pedagogy (WCPWP) to support teaching and learning of Chinese writing among upper primary school students in Mainland China, which could deepen teachers' understanding of the relationship among technology, pedagogy, and content. However, the results indicated that the WCPWP was far more from perfect and there was much room for improvement [6]. Li, Chu and Ki improved the WCPWP [7], which can be named as Developing Wiki-based Collaborative Process Writing Pedagogy (DWCPWP).

More exciting and invigorating, Mixed Between-Within-Subjects ANOVA (two-way RANOVA) indicated that DWCPWP had a significantly positive effect on the writing attitudes of students [7]. However, the results showed that DWCPWP had a positive but insignificant effect on students' writing ability. One of the reasons may be resulted from the unperfected DWCPWP.

Moreover, in current Mainland China, most teachers' understanding of wiki technology is still in its infancy [8], and seldom teachers can really use wiki effectively in their writing courses in practice [7].

Following the above reasons, it is necessary to continue to improve DWCPWP, put forward a more perfect Advanced Wiki-based Collaborative Process Writing Pedagogy (AWCPWP) conceptual model, and help teachers acquire deeper knowledge about organizational requirements for effective use of wiki for teaching-learning of writing.

\section{Methodology}

This study aims to developing an Advanced Wiki-based Collaborative Process Writing Pedagogy (AWCPWP) conceptual model, to equip teachers with TPACK enhancing knowledge, skills, and attitudes related to effective technology integration. In order to fulfill this research aim, this study investigated the attitudes and perceptions of teacher and students towards DWCPWP.

\section{A. Participants}

In this case study, participants included 54 primary four students (with an average age of ten years) from a same class and their Chinese language teacher - Ms. L; the signed informed consent forms from all students, their parents, the teachers and school principal were obtained. The study was 
reviewed and approved by the Human Research Ethics Committee of the University of Hong Kong.

\section{B. Instrumentations}

In this study, both quantitative and qualitative methods were used to collect data. To address the research question, the instruments included course feedback questionnaire (five-point Likert-type scale), a teacher questionnaire (open-ended questions), and student interviews.

The course feedback questionnaire was modified from previous studies [9], [10] and used to explore students' perceptions and attitudes toward the DWCPWP. The questionnaire comprised 30 questions, and the questions were intended to measure five subscales: motivation, interaction , teacher's role, readership and technology.

A questionnaire for the teacher was modified based on previous study [11]. Open-ended questions probed teacher's perceptions and attitudes toward DWCPWP.

Interviews were coded by the researcher into positive themes, negative themes, and other themes modeled after Maercker, Bonanno, Znoj and Horowitz's scheme [12]. Each theme was given a label, the percentage of students contributing to the theme was calculated, and representative statements for each were selected. Focus groups and individual students were presented with the same semi-structured interview questions. 21 randomly selected students were interviewed, including four groups of students (Group Three, Five, Nine, and Eleven). A research assistant cross-checked the coding of the themes, which resulted in an inter-rater agreement score of $95 \%$.

\section{Design Setting of DWCPWP}

Ms. L and the researcher introduced the collaborative process writing pedagogy to students during one lesson. The 54 students were divided into 13 groups: two groups (group 3 and 11) involved five students each and the other 11 groups involved four students each. Ms. L orchestrated students' writing activities based on DWCPWP. Students wrote their compositions following four stages which are: Wiki-based Group Prewriting, Wiki-based Group Drafting, Wiki-based Group Revising, and Wiki-based Group Editing. Students wrote their paper in the third writing community of JWC(http://www.joyouswriting.com/index.php?title= 第 三 社区).

\section{The Attitudes AND Perceptions of Teacher AND STUDENTS TOWARDS DWCPWP}

The course feedback 5-point Likert scale $(1=$ strongly disagree to $5=$ strongly agree) tested students' attitudes and perceptions toward DWCPWP. Table I indicates that motivation had an alpha of 0.60 , group interaction alpha was 0.62 , teacher's role had an alpha of 0.31 , the audience alpha was 0.67 , and the technology alpha was 0.45 . The three subscales of motivation, group interaction and audience indicated moderate reliability [13]. The mean score of each item in the Motivation, Interaction, Audience subscales was higher than 3 (Neutral $=3$ ), and standard deviation was lower than 1.5 , indicating that most students perceived collaborative writing using a wiki as boosting their motivation to write, as well as supporting group interactions and widening the readership of their writings.

Table II summarizes the analysis of interviews with 21 students (supplementary to course feedback questionnaires), and explores student perceptions of the DWCPWP. Related Teacher's Role (33\% students) (see Table II), students also expressed their perceptions:

S6: By using DWCPWP, teacher did not tell us the writing content, but gave us freedom and required us to think for ourselves. As a result, our thinking skills were exercised, so that our writing abilities can be better improved [...]

S14: The teacher's role changed a lot in this writing approach. In DWCPWP, the teacher only told us the basic information on the topic, and let us think ourselves. At the same time, the teacher urged us to finish the first draft in class, which pushed us to think, discuss, and write. All those can help improve our writing abilities [...]

Based on the analysis of the responses to the teacher's questionnaire after the experimental teaching, the Chinese language teacher Ms. L expressed that DWCPWP had a positive effect on improving students writing ability, collaboration ability, reading ability, ability in oral expression, and she was interested in using it in her future teaching activities.

Ms. L: Part of students participated in writing actively, and they had extremely strong writing interests. Students with medium writing ability had more ideas than before; students with low writing ability experienced the joyous side of writing, and they were engaged in writing actively and happily sometimes $[\ldots]$ The DWCPWP had a significant positive effect for students thinking about the way of extracting the central theme and organizing the writing structure. They improved significantly in these two aspects. Moreover, their collaboration and reading abilities and oral expression were improved. Furthermore, the coordination ability of group leaders was improved [...] Wiki helped me to understand students' writing progress in time, as well as gauging their understanding of writing requirements [...] In students' writing process, I played a role as a helper such as helping them reach a consensus when their ideas were different, helping them solve technological problems [...] In the future, I will consider using both DWCPWP and Traditional Individual Product-oriented Writing Pedagogy (TIPWP). Collaborative writing focuses on group collaboration and final composition. Individual writing focuses on all-sides of the individual. Hence, it will be easier for me to understand the writing problems of individual students by using TIPWP to help them. Moreover, introverted students can be too sensitive and shy to collaborate with others, and sometimes it may be better for them to write by themselves [...]

However, the teacher Ms. L also noted the difficulties she and students faced during the writing process. The difficulties can be classified in two categories: collaboration problems and group modification problems. 
Ms. L: Firstly, when students write in groups, there is obvious diversity in performance. Students with lower writing ability rely on students with higher writing ability; secondly, some students find it difficult to adapt themselves to collaborative writing activities; sometimes, it is hard for them to reach a consensus when their ideas are different. Thirdly, some parents do not support collaborative writing on computers at home after class. Fourthly, some groups cannot finish the compositions within the specified time in class. Fifthly, since each student is in charge of parts of the composition, students' consciousness in modifying compositions is very weak $[\ldots]$

In order to help students with their writing, the Chinese language teacher took a series of measures:

Ms. L: I paid attention to students' participation status, encouraged students in the same group to be united, to discuss together, and to learn to give and take in a friendly manner. I encouraged students to report their writing problems to me in time and required group leaders to manage and coordinate their group writing activities. I also sent messages to some parents to gain their support $[\ldots]$

TABLE I: STUDENTS' ATTITUDES AND PERCEPTIONS TOWARD THE DWCPWP

\begin{tabular}{|c|c|c|c|}
\hline Items & Mean & SD & $\begin{array}{l}\text { Subscale } \\
\alpha\end{array}$ \\
\hline Subscale 1: Motivation & & & 0.60 \\
\hline 1. I like writing collaboratively with the "Joyous Writing Club". & 4.72 & 0.53 & \\
\hline $\begin{array}{l}\text { 2. Compared with writing with pen and paper, I prefer writing with the } \\
\text { "Joyous Writing Club" more. }\end{array}$ & 4.68 & 0.64 & \\
\hline 3. I participated in writing more because of the "Joyous Writing Club". & 4.26 & 0.74 & \\
\hline 4. I want to spend more time writing because of the "Joyous Writing Club". & 4.36 & 0.76 & \\
\hline 5. "Joyous Writing Club" increased my interest in writing. & 4.66 & 0.73 & \\
\hline 6. I hope to continue participating in the "Joyous Writing Club" next semester. & 4.72 & 0.57 & \\
\hline Subscale 2: Group Interaction & & & 0.62 \\
\hline 7. I learned a lot from my group members, which enriched my writing content. & 4.43 & 0.84 & \\
\hline $\begin{array}{l}\text { 8. I think that whether or not students collaborate successfully in a group } \\
\text { affects collaborative writing significantly. }\end{array}$ & 4.83 & 0.43 & \\
\hline $\begin{array}{l}\text { 9. In my opinion, communication and interaction among us increase when we wrote with JWC. This } \\
\text { characteristic of JWC helped our writing compared with the traditional writing approach. }\end{array}$ & 4.66 & 0.62 & \\
\hline $\begin{array}{l}\text { 10.In collaborative writing, the conflicting opinions among team members brought } \\
\text { more good than harm. }\end{array}$ & 3.17 & 1.30 & \\
\hline $\begin{array}{l}\text { 11. I think the contribution of every member is important. In order to write } \\
\text { the best composition, everyone needs to try his/her best. }\end{array}$ & 4.72 & 0.74 & \\
\hline $\begin{array}{l}\text { 12. I think interacting with my classmates can improve my writing ability more than only interacting with the } \\
\text { teacher. }\end{array}$ & 4.43 & 0.91 & \\
\hline Subscale 3: Teacher's Role & & & 0.31 \\
\hline $\begin{array}{l}\text { 13. I think that during our collaborative writing process, the teacher } \\
\text { provided us with enough help and direction. }\end{array}$ & 2.70 & 1.40 & \\
\hline $\begin{array}{l}\text { 14. When we wrote with DWCPWP, the teacher left more time for our discussion, and taught us "how to write" } \\
\text { instead of "what to write". This is good. }\end{array}$ & 4.13 & 1.24 & \\
\hline $\begin{array}{l}\text { 15. I think teacher guidance in group writing is very important, which tells us how to write, tells us the writing } \\
\text { process, not only the content of writing. For example, before writing, we should discuss our writing with } \\
\text { group members, and then we write the first draft; after that, we modify the composition together. }\end{array}$ & 4.77 & 0.64 & \\
\hline $\begin{array}{l}\text { 16. By using DWCPWP, I feel the teacher's role has changed. In the past when we wrote only on paper, we } \\
\text { relied too much on the teacher. She told us the content, and our writing centered on content. Now, the } \\
\text { teacher is a collaborator, facilitator, and consultant. }\end{array}$ & 4.17 & 1.09 & \\
\hline 17. In traditional writing, the teacher instilled the writing content into our minds. When we wrote with & & & \\
\hline $\begin{array}{l}\text { DWCPWP, the teacher guided us to think and discuss more, and gave us more autonomy and freedom, } \\
\text { which is good for improving our writing ability. }\end{array}$ & 4.60 & 0.77 & \\
\hline $\begin{array}{l}\text { 18. In the collaborative writing course with wiki, the teacher mainly guided and helped our collaborative writing } \\
\text { activities. Compared with the teacher's role in the past, the teacher's role in DWCPWP is more helpful for } \\
\text { improving our thinking ability. }\end{array}$ & 4.55 & 0.77 & \\
\hline Subscale 4: Audience & & & 0.67 \\
\hline $\begin{array}{l}\text { 19. Since more people can know our compositions through JWC, I have become } \\
\text { more active in writing. }\end{array}$ & 4.42 & 0.89 & \\
\hline $\begin{array}{l}\text { 20. I feel that there is a larger readership for our compositions on JWC, which is one of the } \\
\text { advantages of the DWCPWP. }\end{array}$ & 4.21 & 1.18 & \\
\hline $\begin{array}{l}\text { 21. Every time I think of a lot of people can read my composition through JWC, I am more keen to write, write } \\
\text { seriously and improve my writing. }\end{array}$ & 4.45 & 0.85 & \\
\hline 22. I want my composition to be read by many people, so I like to write through JWC. & 4.53 & 0.87 & \\
\hline $\begin{array}{l}\text { 23. When I was writing with JWC, my classmates, parents, and my teacher become the readership of my } \\
\text { composition, which inspired me. }\end{array}$ & 4.47 & 0.80 & \\
\hline $\begin{array}{l}\text { 24. When I was writing with JWC, the large readership brought me pressure, which drove me } \\
\text { to improve my writing. }\end{array}$ & 4.57 & 0.84 & \\
\hline Subscale 5: Technology & & & 0.45 \\
\hline 25. Writing with "Joyous Writing Club" brought us more technological advantages than disadvantages & 3.32 & 1.44 & \\
\hline 26. When I wrote with JWC, both reviewing and editing were easy. & 4.13 & 1.09 & \\
\hline
\end{tabular}




\begin{tabular}{|c|c|c|}
\hline 27. The technological characteristics of wiki, such as open editing functions are good for our writing. & 4.70 & 0.80 \\
\hline 28. The interface and features of the "Joyous Writing Club" were easy to be understood. & 4.00 & 1.35 \\
\hline $\begin{array}{l}\text { 29. We feel that the website of JWC is easy to use, but the computer and network problems brought us trouble } \\
\text { sometimes. }\end{array}$ & 4.79 & 0.50 \\
\hline 30. When we wrote at home, the website of JWC was easy to use. & 4.83 & 0.43 \\
\hline
\end{tabular}
Notes. $\mathrm{N}=54$ ** The standards for Cronbach alpha reliability value for evaluating attitude measures were: 0.80 or better - exemplary reliability; $0.70-0.79-$ extensive reliability; $0.60-0.69$ - moderate reliability; and $<0.60$ - minimal reliability [13].

TABLE II: SUMMARY OF INTERVIEW FINDINGS

\begin{tabular}{|c|c|c|c|}
\hline Positive Themes & $\mathbf{N}$ & Percentage & Examples \\
\hline Motivation & 19 & $91 \%$ & $\begin{array}{l}\text { After writing with the "Joyous Writing Club", I like writing more (S4), and I hope to continue } \\
\text { writing on JWC next semester (S16). }\end{array}$ \\
\hline Learning Benefits & 17 & $81 \%$ & $\begin{array}{l}\text { Improved my writing ability (S1), writing interest (S1), computer skills (S2), and } \\
\text { collaborative ability (S2). }\end{array}$ \\
\hline Group Interaction & 19 & $91 \%$ & $\begin{array}{l}\text { By using DWCPWP, we write collaboratively within a group, we have chances to } \\
\text { communicate with group members, share our ideas, gather our strength together (S6); I did not } \\
\text { feel lonely (S16); and it reduced my writing pressure (S16); we enjoy writing in groups, it } \\
\text { makes writing interesting (S17). }\end{array}$ \\
\hline $\begin{array}{l}\text { Technology } \\
\text { Advantages }\end{array}$ & 13 & $62 \%$ & $\begin{array}{l}\text { Collaborative writing becomes easier by using JWC, since a group of students could write } \\
\text { anytime in and after class (S3); it eased peer editing and modification (S5); it was easier to } \\
\text { organize different member's writing together (S11). }\end{array}$ \\
\hline Readership & 18 & $86 \%$ & $\begin{array}{l}\text { A larger readership motivated writing (S4); at the same time, as part of the readership } \\
\text { themselves, they learned from others' compositions (S11). }\end{array}$ \\
\hline Group Modification & 14 & $67 \%$ & $\begin{array}{l}\text { We can modify our compositions repeatedly (S4); the group modification lets us know our } \\
\text { mistakes, which is very impressive ( } \mathrm{S} 14) \text {. }\end{array}$ \\
\hline Comments & 18 & $86 \%$ & $\begin{array}{l}\text { Students from other groups comment on our writing and we can know the weaknesses and } \\
\text { strengths of others' writing (S4); we comment on others' writing based on the Rating Criteria } \\
\text { of Compositions, which helps me understand identify the quality of writing (S13) }\end{array}$ \\
\hline \multicolumn{4}{|l|}{ Negative Themes } \\
\hline $\begin{array}{l}\text { Collaboration } \\
\text { Problems }\end{array}$ & 6 & $29 \%$ & $\begin{array}{l}\text { Some members did not write, or wrote very few words (S7); sometimes, it was difficult to } \\
\text { manage those group members as a group leader (S14). }\end{array}$ \\
\hline Time Issue & 3 & $14 \%$ & $\begin{array}{l}\text { Sometimes, the class time was too short for us to finish our writing. Group communication } \\
\text { was inconvenient after class which generally increased the difficulty of writing (S7). }\end{array}$ \\
\hline $\begin{array}{l}\text { Technology } \\
\text { disadvantages }\end{array}$ & 5 & $24 \%$ & $\begin{array}{l}\text { Sometimes, the system built-in edit buttons were hard to be used (S2). Website and computer } \\
\text { problem hindered our writing (S4). }\end{array}$ \\
\hline Computer Skills & 3 & $14 \%$ & I type words very slowly and it is difficult for me to write using a computer (S4). \\
\hline \multicolumn{4}{|l|}{ Other Themes } \\
\hline Teacher's Role & 7 & $33 \%$ & $\begin{array}{l}\text { By using DWCPWP, the teacher taught less, let us think and write ourselves, but helped us } \\
\text { with difficulties during the writing process (S14); in the traditional writing class, we rely a lot } \\
\text { on the teacher regarding the content of writing and, as a result, our compositions are all } \\
\text { similar; by using DWCPWP, the teacher can inspire our thinking, and we rely on ourselves } \\
\text { and group members (S19). }\end{array}$ \\
\hline
\end{tabular}

\section{DISCUSSION}

Based on the results, in order to help teachers to teach writing effectively and orchestrate the writing activities with wiki, this study put forward a conceptual model of AWCPWP (Fig. 3).

By using AWCPWP, collaborative learning in writing could balance the authority of students and teachers, and students participate in their own learning through peer editing and group writing.

During the students' collaborative writing process, the Chinese language teacher plays the roles as a guider, manager and examiner. As a guider, teacher mainly guides students to use the wiki website, to write composition following the group writing activities (Table III). Besides, based on the results, students expressed mutual comments among different groups are very important. Hence, teachers need require different groups reciprocally read different group works, compare different groups' compositions, and comments on other groups' compositions. As a manager, teacher mainly manages the wiki website, and students' writing activities (Table III). Teacher need orchestrate students' collaborative writing process carefully, the four stages were simplified into three stages:

Group Prewriting, Group Drafting, and Group Consummating (Table III). This is because the subtle differences and similarity of the suggested activities between stages of group revising and group editing. As an examiner, teacher need formulate standard Rating Criteria, and evaluate the learning performance of every student reasonably. 
The three stages can be linear, nonlinear or recurrent, and every group member shall monitor the progress. Through the collaborative writing process, students were better prepared for independent writing once they learned to go through these writing stages to develop their own writing strategies [14].

In order to effectively help teachers facilitate the writing process which is real, achievable, exciting, and nonthreatening, nine important characteristics related to wiki-based collaborative process writing were refined (Fig. 1), and they are:

1) Group members with different levels of writing ability, but can perform the same action. In this study, a four-member student group comprises of two students with better writing ability and two students with weaker writing ability. Based on the Zone of Proximal Development (ZPD) theory, students with weaker writing skills can better complete writing with the assistance of more capable peers [15].

2) Common goals. Mercer and Littleton [16] have also emphasized the importance of shared goals. Students need to set common goals such as determining the writing topic, writing structure, the theme of each paragraph and so on.

3) Group brainstorming and planning. Group brainstorming and planning are very important for students to exercise their imaginations. With vivid and bright imaginations, students could plan their writing theme, topic, and content better.

4) Negotiation, reciprocity and shared ideas. Based on young children's egocentric cognitive structure, children aged between 7 to 11 become less egocentric, more able to simultaneously take into account others' point of view
[17]. However, children still tend to project their own thoughts and wishes onto others. For example, some group leaders acted arbitrarily and dictatorially, group members often quarreled with each other during discussion and were not convinced. Hence, in collaboration, students are required to negotiate and share ideas with each other. Reciprocity is a basic principle in negotiation.

5) Division of labor. The whole composition needs to be divided into different parts, and different group members are tasked to write different paragraphs.

6) Sequential writing on the same wikipage. Wiki is an asynchronous tool which enables communication and collaboration through a "different time" mode. Each group member drafts their own paragraph individually based on the shared goals, topic, structure, and the theme of each paragraph. Different students must write their own parts (or copy their writing from Microsoft Word and paste) on the same wikipage sequentially.

7) Open-minded revision with mutual respect. Revision is very important for students to improve and perfect their writing. Importantly, this study found that students are required to discuss with peers when they want to revise peers' writing. Children's morality developed through interpersonal interactions as they worked out resolutions which all deemed fair [17], [18].

8) Save. Last but not least, it is very important for children to keep saving their work in time.

By using an AWCPWP, the suggested writing activities and characteristics in the three group writing stages are in accordance with children's own learning characteristics [17], [18] and wiki's technological affordances.

TABLE III: GROUP WRITING ACTIVITIES BASED ON AWCPWP

\begin{tabular}{|c|c|}
\hline Writing Stages & Details \\
\hline $\begin{array}{l}\text { Wiki-based Group } \\
\text { Prewriting }\end{array}$ & $\begin{array}{l}\text { 1. The key stage: more attention, thought and preparation at this stage can save time and effort later. } \\
\text { 2. Each student need consider the writing topic, theme, context, and genre of group writing, discuss either face-to-face or } \\
\text { online. } \\
\text { 3. Negotiate the division of labor, group members' tasks, the theme of each paragraph, and reach agreement before } \\
\text { drafting. Most groups can deliver different paragraphs to different group members. } \\
\text { 4. Facing differences of opinions, students must choose one method (e.g., majority rule) to solve. } \\
\text { 5. Group leaders should be responsible for the organization and management of group members, should respect other } \\
\text { members' ideas, and should not be arbitrary. } \\
\text { 6. Gather ideas and information by reading books, surfing online and through discussions with group members. }\end{array}$ \\
\hline $\begin{array}{l}\text { Wiki-based } \\
\text { Group } \\
\text { Drafting }\end{array}$ & $\begin{array}{l}\text { 1. In this stage, group members need to write the first draft together on group wikipage. } \\
\text { 2. Since wiki is an asynchronous tool (discussion boards, wikis, blogs and journals), which does not allow communicating } \\
\text { on the same page at the same time. Hence, students must adopt serial collaboration, i.e., work on compositions one } \\
\text { after another. } \\
\text { 3. Each student needs to work separately on a piece of writing based on the division of labor, and perform a distinct } \\
\text { function in creating the finished work. } \\
\text { 4. Organize the structure and express your ideas and feelings quickly, and with little concern about character writing, } \\
\text { correctness and punctuation. At this stage, the theme and content of writing take priority. } \\
\text { 5. Save work on wiki in time. }\end{array}$ \\
\hline $\begin{array}{l}\text { Wiki-based } \\
\text { Group } \\
\text { Consummating }\end{array}$ & $\begin{array}{l}\text { 1. In this stage, revisions and editing take place during the process of writing and at the end of the process. } \\
\text { 2. Group consummating is a complex process comprising two activities: rereading the draft and revising based on one's } \\
\text { own idea, others' comments and feedbacks. } \\
\text { 3. Revise the draft in class or at home. Students can do some face changes (e.g., correcting spelling and punctuation } \\
\text { errors) or text-based changes (e.g., micro or macro structure changes) } \\
\text { 4. Discuss with peers before revising the group writing, which can show respect to peers, and motivate them to be } \\
\text { involved. } \\
\text { 5. Edit and format group work again on the wiki a few days after finishing the first draft, and this may provide students } \\
\text { with a new perspective and enthusiasm which is necessary for finishing the writing process. } \\
\text { 6. At the end, the leader needs to confirm the completion of the writing. }\end{array}$ \\
\hline
\end{tabular}




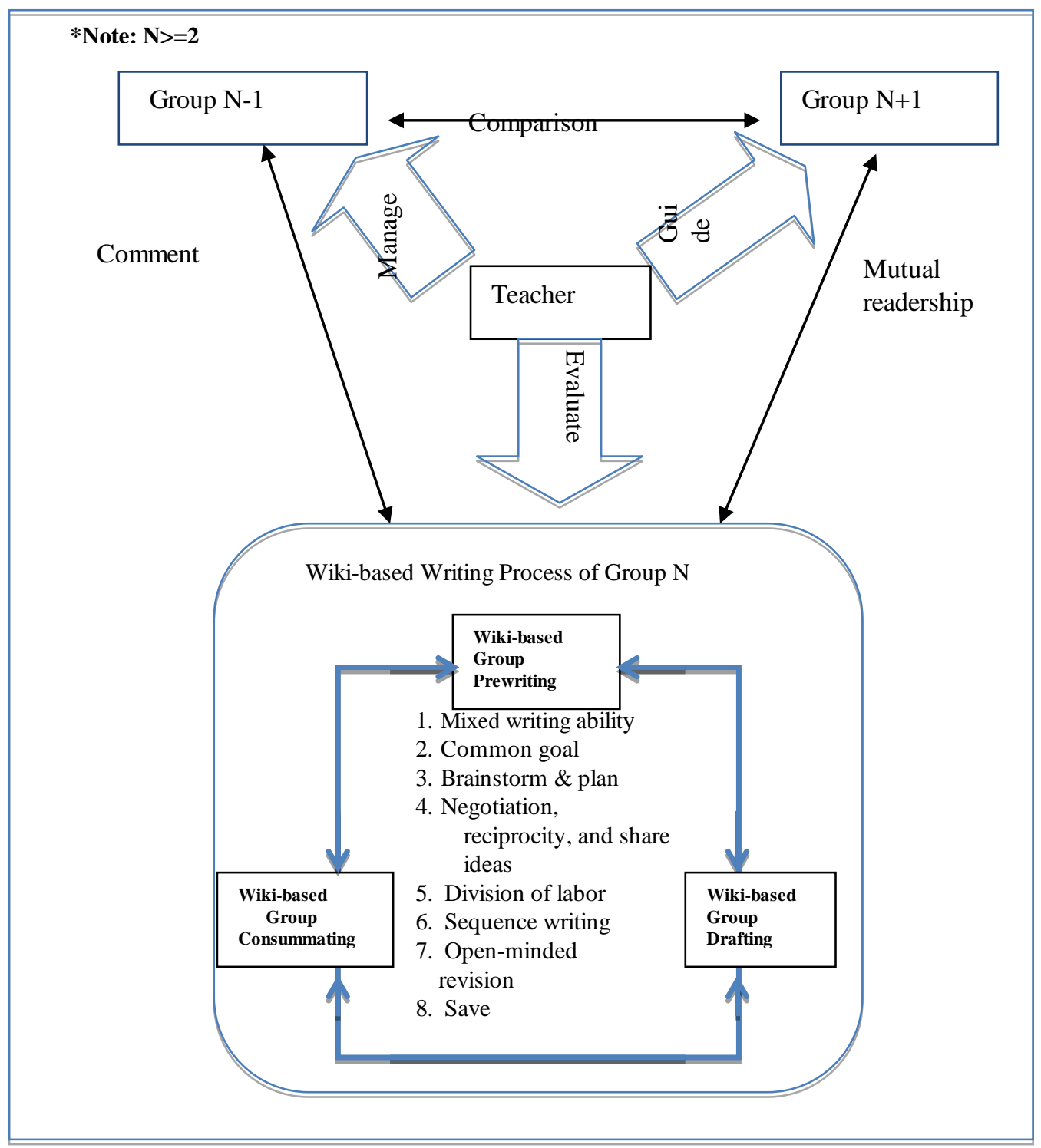

Fig. 1. Conceptual model of advanced Wiki-based collaborative process writing pedagogy.

\section{SUMMARY}

Preparing teachers for effective technology integration is an ongoing challenge, which is foremost importance and more crucial than acquiring a large number of computers. This study provides an example of capitalizing on TPACK framework as a tool for thinking about and applying wiki meaningfully to support collaborative writing among upper primary school students in Chinese context, may help them bring wiki effectively into their writing courses in reality, and deepen their understanding about TPACK.

This study has several limitations. The first limitation is the small sample size used. This study involved 54 students and their Chinese language teacher. The small sample used in this study might influence results. The second limitation concerns the wiki-based writing environment, the Joyous Writing Club (JWC), designed and developed by the researcher. Many advanced wikis (e.g., PBworks.com) are blocked by the Great Firewall of China. In order to carry out this study safely, the researcher designed and developed the JWC in 2011 using a MediaWiki (version 1.15.1). The latest version of MediaWiki is version 1.28 [19]. Most added functions in the latest version did not change the characteristics of MediaWiki. Hence, the research results can be supposed to be similar even adopt the latest version (version 1.27) of MediaWiki in this study.

Several recommendations for future research are proposed. First, it is preferable to use larger samples. Second, in future studies, more advanced and user-friendly wiki websites like PBworks.com and Wikispaces.com with a Chinese interface and more powerful functions can be designed and used in Mainland China. Third, the design, application and evaluation of the Advanced Wiki-based Collaborative Process Writing Pedagogy (AWCPWP) should be further improved and investigated in future studies. For example, this study did not analyze revisions and comments (in the collaborative writing process) in depth. This area deserves investigation by future researchers.

\section{ACKNOWLEDGMENT}

The author wishes to thank Dr. Chu, Samuel K.W., of the Faculty of Education, the University of Hong Kong, for his support in this research. 


\section{REFERENCES}

[1] P. Mishra and M. J. Koehler, "Technological pedagogical content knowledge: A framework for teacher knowledge," Teachers College Record, vol. 108, no. 6, pp. 1017-1054, 2006.

[2] C. M. Angeli and N. Valanides, "Epistemological and methodological issues of the conceptualizations, development and assessment of ICT-TPACK: Advancing technological pedagogical content knowledge (TPCK)," Computers and Education, vol. 52, pp. 154-168, 2009.

[3] M. Padmavathi, "Preparing teachers for technology based teaching-learning using TPACK," I-Manager'S Journal on School Educational Technology, vol. 12, no. 3, 2017.

[4] D. Cră ciun and M. Bunoiu, "Developing pre-service science teachers tpack confidence through web based comics," in Proc. the 13th International Scientific Conference eLearning and Software for Education. Bucharest, April 27-28, 2017.

[5] J. B. Harris and M. Hofer, "Technological pedagogical content knowledge (TPACK) in action: A descriptive study of secondary teachers' curriculum-based, technology-related instructional planning,' Journal of Research on Technology in Education, vol. 43, no. 3, pp. 211-229.

[6] X. X. Li, Samuel K. W. Chu, and Wing Wah Ki. (2014). The effects of a wiki-based collaborative process writing pedagogy on writing ability and attitudes among upper primary school students in Mainland China. Computers and Education. [Online]. 77. pp. 151-169. Available: http://dx.doi.org/10.1016/j.compedu.2014.04.019

[7] X. X. Li, Samuel K. W. Chu, Wing Wah Ki, and M. Woo. (2012). Using a wiki-based collaborative process writing pedagogy to facilitate collaborative writing among Chinese primary school students. Australasian Journal of Educational Technology. [Online]. 28(1). Available: http://www.ascilite.org.au/ajet/ajet28/li.html

[8] H. S. Wu and X. M. Li, "The application of wiki in the teaching of network composition educational technology," vol. 3, pp. 84-85, 2013.

[9] S. Hazari, A. North, and D. Moreland. (2009). Investigating pedagogical value of wiki technology. Journal of Information Systems Education, [Online]. 20(2). pp. 187-198. Available: http://jise.org/Volume20/20-2/Pdf/V20N2P187-abs.pdf
[10] S. T. Liang, "Effects of online peer assessment upon the sixth-graders' learning of writing," Unpublished master Thesis, National Central University, Taipei, 1995.

[11] M. Woo, S. K. W. Chu, A. Ho, and X. Li, "Collaborative writing with a wiki in a primary five English classroom," presented at the the 6th International Conference on Knowledge Management, 2009.

[12] A. Maercker, G. A. Bonanno, H. Znoj, and M. J. Horowitz, "Prediction of complicated grief by positive and negative themes in narratives," Journal of Clinical Psychology, vol. 54, no. 8, pp. 1117-1136, 1998.

[13] J. P. Robinson, P. R. Shaver, and L. S. Wrightsman, Measures of Personality and Social Psychnological Attitudes, San Diego, California: Academic Press, 1991.

[14] G. E. Tompkins, Literacy for the 21st Century: A Balanced Approach, 5th Ed. Boston: Allyn \& Bacon, 2008.

[15] L. S. Vygotsky, Mind in Society: The Development of Higher Psychological Processes, Cambridge, MA: Harvard University Press, 1978.

[16] N. Mercer and K. Littleton, Dialogue and the Development of Children's Thinking: A Sociocultural Approach, London: Routledge, 2007.

[17] J. Piaget, The Moral Judgement of the Child, New York: Harcourt, 1932.

[18] J. Piaget, The Theory of Stages in Cognitive Development, IN D. R. Green, M. P. Ford \& G. B. Flamer, Eds. Measurement and Piaget. New York: McGraw-Hill, 1971.

[19] MediaWiki. (2017). Welcome to MediaWiki.org. [Online]. Available: https://www.mediawiki.org/wiki/MediaWiki.

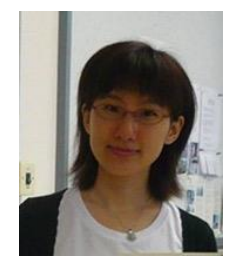

Xuanxi Li is a lecturer in educational technology in School of Education at Shanghai Normal University. She is also a member of Research Institute for International and Comparative Education at Shanghai Normal University. She has a Ph.D. in the field of social media assisted collaborative learning from the University of Hong Kong. She has great interest in mobile learning, multimedia learning, 21st Century skills and TPACK. Besides, she is a novelist for kids. 